\section{NIEUW OVERZICHT MEDISCHE GESCHIEDENIS}

Prof.dr. H.F.P. Hillen, prof.dr. E.S. Houwaart, prof.dr. F.G. Huisman [redactie]. Leerboek medische geschiedenis. Houten: Bohn Stafleu van Loghum, 2018. 243 pagina's. ISBN 9789036819893. Prijs $€ 34,99$.

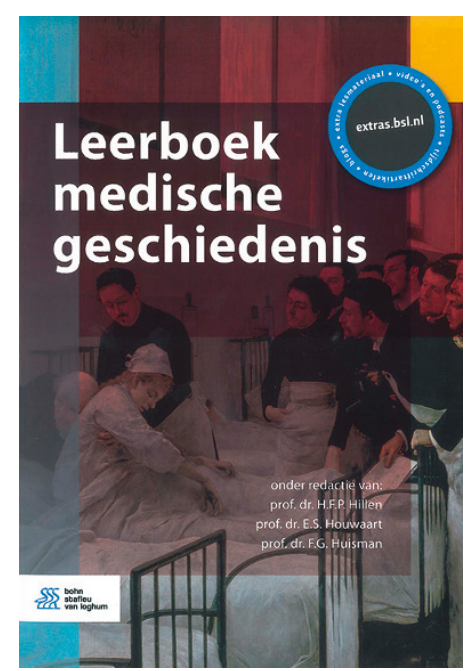

Het laatste boek over medische geschiedenis verscheen meer dan dertig jaar geleden. Alleen de Canon der Geneeskunde van Nederland (2009) is jonger, maar een canon is per definitie vrij fragmentarisch van opzet. Het werd dan ook tijd voor een nieuw boek over medische geschiedenis.

De opzet van dit boek, geschreven door drie hoogleraren van naam (Hillen,

Houwaart en Huisman), is veel moderner dan het boek uit de jaren tachtig. Het boek bestaat uit vier delen: 1. Ziekte, 2. Kennis, 3. Dokter en patiënt, 4. Gezondheidszorg en maatschappij. In zeventien hoofdstukken van elk twaalf tot veertien pagina's werken de veertien auteurs de ontwikkelingen van een groot aantal thema's uit. Elk hoofdstuk begint met leerdoelen en eindigt met leervragen. Ook bevat elk hoofdstuk een unieke activeringscode die toegang geeft tot de website van het boek. Daar kunt u niet alleen de antwoorden vinden op de leervragen, maar bijvoorbeeld ook verdiepingsartikelen, video's of podcasts. Overigens is het ene hoofdstuk beter geillustreerd dan het andere.

Natuurlijk kunnen niet alle onderwerpen in 240 pagina's de revue passeren. Kenmerkend in het boek is de grote lijn die de auteurs schetsen in de tijd. Vooral de ontwikkeling van de geneeskunde en gezondheidszorg na 1800 komt goed in beeld, met name thema's als de psychiatrie en de openbare gezondheidszorg. Toch mis ik een aantal belangrijke zaken, zoals verdwenen ziektebeelden als chlorose en de psychogene maagzweer, en attributen zoals de aderlaatvlijm en de klisteerspuit die eeuwenlang de viersappenleer dienden. Ook Nederlandse ontdekkingen zoals de Graafse follikel (1672) en het gipsverband van Mathijsen (1851) kom je in dit boek niet tegen. Zelfs de gehele ontwikkeling van de verloskunde zocht ik tevergeefs, dus niet alleen de verlostang van Palfijn...

Voor huisartsen en studenten geneeskunde biedt het boek een helder overzicht zonder teveel jaartallen, met nadruk op de ontwikkeling, de dilemma's en de keuzes in de gezondheidspolitiek na 1850 .

Jan van Eijck, lid werkgroep Geschiedenis van de Huisartsgeneeskunde

\section{WAARDERING:}

\section{COLOFON}

Huisarts en Wetenschap wordt uitgegeven door het Nederlands Huisartsen Genootschap [NHG], de wetenschappelijke vereniging van huisartsen. www.henw.org.

\section{Redactie}

Ivo Smeele [hoofdredacteur], Marian van den Brink, Ben Crul, Marianne Dees, Mirrian Hilbink, Sjoerd Hobma, Victor van der Meer, Nadine Rasenberg, Annet Sollie, Wim Verstappen.

\section{Redactiesecretariaat}

Henny Helsloot [secretaresse], Judith Mulder [web- en eindredactie], Susan Umans [bladmanagement], Anita Wittebol [office manager], Steven de Kock, Marjolein Oosterom, Wouter Scheen [eindredactie], Margot

Scheerder, Wendy Westerhof [beeldredactie].

Postbus 3231, 3502 GE Utrecht, tel. 030-2823550, redactie@nhg.org

\section{Uitgever}

Bohn Stafleu van Loghum, Postbus 246, 3990 GA Houten

Basisvormgeving Frederik Helfrich, Deventer

Auteursinformatie: www.henw.org

\section{Advertentieverkoop}

Advertentieverkoop: adverteren@bsl.nl, tel. 030-6383603.

Advertenties behoeven goedkeuring van de redactie.

Inzenden aan: traffic@bsl.nl, tel.030-6383874.

\section{Abonnementen}

H\&W verschijnt 12 keer per jaar en wordt verspreid onder de leden van het NHG. Niet-leden kunnen zich abonneren via www.bsl.nl. Abonnementsprijs: [print + online toegang] € 258,00, Online-only abonnement € 154,80. Studenten 50\% korting.

Abonnementen worden automatisch verlengd tenzij 2 maanden voor de vervaldatum schriftelijk opgezegd. Voorwaarden: www.bsl.nl/ klantenservice/abonnementen

Info: Klantenservice, Postbus 246, 3990 GA Houten, tel. 030-6383736.

\section{Voorwaarden}

Op leveringen en diensten zijn de bij de Kamer van Koophandel gedeponeerde algemene voorwaarden van Springer Media B.V. van toepassing. Zie www.bsl.nl/voorwaarden. 